\section{High Tunnel and Field System Comparison for Spring Organic Lettuce Production in Georgia}

\author{
Theekshana C. Jayalath and George E. Boyhan \\ Department of Horticulture, University of Georgia, 1111 Plant Sciences \\ Building, Athens, GA 30602
}

Elizabeth L. Little
Department of Plant Pathology, University of Georgia, 2106 Plant Sciences
Building, Athens, GA 30602

Robert I. Tate and Suzanne O'Connell ${ }^{\mathbf{1}}$

Department of Horticulture, University of Georgia, 1111 Plant Sciences Building, Athens, GA 30602

Additional index words. hoop house, local markets, bolting, Sclerotinia sclerotiorum, photosynthetically active radiation, leaf wetness, protected agriculture

\begin{abstract}
High tunnels may help mitigate unfavorable climate and weather on lettuce (Lactuca sativa L.) production leading to greater yields and quality, yet information for using these systems in the Southeast region is lacking. This study evaluated the effect of high tunnels and three planting dates (PDs) (early March, late-March, and mid-April) on spring organic lettuce production. A $25 \%$ to $36 \%$ increase in marketable fresh weight for butterhead and romaine lettuce, respectively, was observed under high tunnels compared with the field in 2016, but there was no difference among the two growing systems in 2015. High tunnel lettuce was harvested $\approx 2$ to 7 days earlier than in the field in 2015 and 2016, respectively. Pest and disease pressure (e.g., Sclerotinia sclerotiorum) as well as the incidence of physiological disorders (i.e., bolting, tip burn, and undersized heads) were similar between the two systems indicating that our high tunnel system did not provide a benefit for these issues. High tunnel air temperatures were $\approx 3$ to $5{ }^{\circ} \mathrm{C}$ greater on the coldest mornings and only $1^{\circ} \mathrm{C}$ greater on the warmest days compared with the field. Average relative humidity (RH), leaf wetness, and light levels were all lower under the high tunnels. Our results indicate that high tunnels can help increase the production of spring organic lettuce in Georgia, but that the advantage may depend on yearly weather conditions.
\end{abstract}

Lettuce (Lactuca sativa L.) is a popular, cool-season vegetable with a total U.S. production value of nearly $\$ 1.5$ billion in 2013 (AgMRC, 2015). From 2005 to 2011, the amount of U.S. farmland allocated to the organic lettuce production increased from $4 \%$ to $12 \%$, was worth $\$ 264$ million in sales, and was the number one organic crop commodity (ERS, 2013; USDA, 2015). Currently, most of the organic lettuce is produced in California and Arizona (Toland and Lucier, 2011). Georgia can grow lettuce; however, as is typical of the Southeast region,

Received for publication 12 July 2017. Accepted for publication 5 Oct. 2017.

We are grateful for funding provided by a private foundation that wishes to remain anonymous and by the National Institute of Food and Agriculture, U.S. Department of Agriculture, under award \#GS15-147 through the Southern Sustainable Agriculture Research and Education program.

We also like to acknowledge the assistance of Hannah Bundy and the peer reviewers.

${ }^{1}$ Corresponding author. E-mail: soco@uga.edu.

This is an open access article distributed under the CC BY-NC-ND license (http://creativecommons. org/licenses/by-nc-nd/4.0/). increase in extreme precipitation events (EPA, 2016; Kunkel et al., 2013).

Precipitation and related periods of high $\mathrm{RH}$ may increase the incidence of fungal diseases, soilborne diseases or both, whereas strong winds can tear and abrade lettuce leaves. Precipitation events before or during the crop season can also delay field preparation activities. Management techniques such as high tunnels that increased crop protection and the ability to manipulate the crop microenvironment have the potential to increase yield and quality of lettuce production in Georgia.

High tunnels (i.e., hoop houses) are unheated, passively ventilated greenhouse-like structures which can provide some protection to crops from adverse weather events (i.e., cold, precipitation, wind, soil splash back, etc.), selected pests and diseases, or season extension (Alves et al., 2014; Borrelli et al., 2013; Carey et al., 2009; O'Connell et al., 2012; Rogers and Wszelaki, 2012). Early or late season extension may help growers receive premium prices (Alves et al., 2014; Sydorovych et al., 2013) and attract new customers. Furthermore, farmers that use high tunnels may be able to obtain a greater yield or higher quality product by manipulating the microenvironment compared with the field.

High tunnel benefits and management practices are often regionally specific because of local climate characteristics and market preferences. The following research efforts have been executed by others and provided a basis for our project goals which focus on challenges for high tunnel lettuce production in warm, humid regions. An organic high tunnel lettuce study conducted in Tennessee (TN), Texas, and Washington (WA) evaluated season extension; they observed greater bolting incidence in the field compared with under high tunnels in the regions where temperature fluctuations were more frequent (Wallace et al., 2012). A summer lettuce study conducted in Kansas found lower bolting rates when shadecloth was used in conjunction with high tunnels compared with the field but recommended further investigations (Zhao and Carey, 2009). A lettuce study conducted in South Carolina (SC) evaluated the best PDs for yield and quality in the field (Dufault et al., 2006). These researchers observed increased bolting when lettuce was planted in September, October, February, and March, but bolting rates were not different with PDs from November through January. Cultivar choice also influenced days to harvest and yield in this SC study (Dufault et al., 2006). A study conducted in WA determined that winter high tunnel production of Asian greens, spinach, and lettuce was possible, but could be optimized with more informed cultivar selection, seeding dates, and planting densities (Borrelli et al., 2013). A study conducted in North Carolina to evaluate the performance of organic tomatoes in high tunnels suggested that with proper management, one can achieve better yields, increased fruit 
quality, and provide season extension opportunities (i.e., early spring fruit) for high-value horticultural crops (O'Connell et al., 2012). Another high tunnel tomato study in TN found that high tunnel tomatoes had increased marketability and size and benefitted from earlier PDs compared with the field (Rogers and Wszelaki, 2012).

The Southeastern region's mild winters present opportunities to grow crops from fall through spring seasons under high tunnels as they may help protect crops from abiotic stressors including cold temperatures, precipitation, wind, etc. However, managing excessive heat during late spring through early fall presents a challenge for growing cool-season crops such as lettuce under high tunnels. Therefore, the goals of this study were to evaluate the effect of high tunnels and $\mathrm{PD}$ on early to late spring organic lettuce production in Georgia. Objectives included a comparison of 1) butterhead and romaine lettuce yields grown under high tunnels and the field, 2) butterhead and romaine lettuce yields among three spring PDs, and 3) microenvironmental data for both types of production systems.

\section{Materials and Methods}

Site characteristics and history. The experiment was conducted during the spring of 2015 and 2016 at the Durham Horticulture Farm, located in Watkinsville, GA (lat. $33^{\circ} 53^{\prime} 12.804^{\prime \prime} \mathrm{N}$, long. $-083^{\circ} 25^{\prime} 9.876^{\prime \prime} \mathrm{W}$ and elevation $236 \mathrm{~m}$ ). The plant hardiness zone for the site is 8a (USDA, 2012). The soil type at the site was a well-drained Cecil sandy clay loam subsoil (CYB2) that has been eroded overtime so the plow layer now extends into the red sandy loam subsoil (USDA, 1968). Soil analysis in high tunnel and field areas indicated a $\mathrm{pH}$ of $\approx 6.6$ and a composition of $67 \%$ sand, $15 \%$ silt, and $18 \%$ clay before the experiment (Agricultural \& Environmental Services Laboratories, Athens, GA). The project site has been certified organic since 2012, and all agricultural production methods were performed under USDA regulations 7 U.S.C. $\$ 6507$.

High tunnel design. Two commercial-size gothic-shaped high tunnels (Atlas Greenhouse Inc., Alapaha, GA) $(29.3 \times 9.1 \times 3.7$ $\mathrm{m})$ and a comparative field area $(45.7 \times 9.1$ $\mathrm{m})$ in close proximity to the high tunnels ( $\approx 5 \mathrm{~m}$ to the north) were used for the study. High tunnels were oriented east-west, to be perpendicular to the prevailing winter winds at the site. The field was also oriented eastwest. High tunnels had inflated double polyethylene film roofs that comprised 152.4-um plastic with $90 \%$ light transmission, 25\% light diffusion, and 95\% blocking of ultraviolet wavelengths $<350 \mathrm{~nm}$ (SunView 4; POLY-AG. Corp., San Diego, CA). The end walls comprised 8-mm thick polycarbonate. Automated $1.83 \mathrm{~m}$ tall z-lock drop-down side curtains constructed from 304.8-um weave fabric were used. In both years, before our experiment, the field area was planted with an oat cover crop (Avena sativa) at a rate of 112 $\mathrm{kg} \cdot \mathrm{ha}^{-1}$ (Welter Seed and Honey Co., Onslow, IA) and high tunnel areas planted with a variety of Brassicaceae cash crops across the 2014-16 Fall/Winter seasons before lettuce.

Transplant management. Butterhead and romaine lettuce plants were grown in an organic greenhouse with air temperature set points at $13{ }^{\circ} \mathrm{C} / 21{ }^{\circ} \mathrm{C}$ (nighttime/daytime). Seeds were sown into six-pack trays $(4 \times 4 \times$ $6 \mathrm{~cm}$ ) (\#L-1206; Land Mark Plastics, Akon, ural \& Organic Professional Growing Mix \#1; Sun Gro Horticulture, Agawam, MA). A soluble fish and seaweed fertilizer [AgGrand Organic Series (4N-1.3P-2.5K); Amsoil, Inc., Superior, WI] was applied once per week at a rate of $7.82 \mathrm{~mL} \cdot \mathrm{L}^{-1}$ of water during the third, fourth, and fifth week after sowing. Seedlings were acclimated to the outside environment about $7 \mathrm{~d}$ before transplanting to either high tunnel or field systems. When night temperatures during the acclimation period were predicted to be $\leq 4{ }^{\circ} \mathrm{C}$, transplants were covered with 18.6 $\mathrm{g} \cdot \mathrm{m}^{-1}$ weight rowcovers (Gro-Guard ultraviolet Row Cover \#20; Atmore Industries, Atmore, AZ). On one evening when the temperatures were predicted to be $\leq 0{ }^{\circ} \mathrm{C}$, transplants were brought back into the greenhouse to avoid cold damage.

Site preparation. Eight raised beds $(71 \mathrm{~cm}$ wide $\times 20 \mathrm{~cm}$ tall), oriented east-west, were prepared under both the high tunnels and the field. Two beds parallel to the side walls in high tunnels or lateral edges of field plots were designated as guard rows to minimize differential effects from environmental factors such as wind and light. About $65 \%$ of the experimental area was planted with lettuce and remainder was footpaths and other workspaces.

Fertilizers were applied 1 week before planting. Application rates were based on soil sampling results conducted 1 month before the first lettuce PD each year. In 2016, soil tests recommended adding potassium and magnesium to the field only. It is possible that this was due to different crop histories in each area before 2016 (i.e., a brassica cash crop under the high tunnels and a winter oat cover crop in the field) or lower leaching rates under the high tunnels due to lack of precipitation. Therefore, different fertilizer $\mathrm{OH}$ ) filled with potting soil (Sunshine Nat-

products and rates were applied to high tunnels and field to meet the nutrient requirements for sulfur, potassium, and magnesium required by the lettuce crop (Table 1). The nitrogen requirement was consistent for the high tunnels and field across both years (Table 1). Fertilizers were broadcasted over each planting bed by replicates and incorporated using rakes. Beds were irrigated for several hours by using drip tape before transplanting.

Experimental design. The experiment was a split-split plot design with four replications (i.e., two replications per commercial-sized high tunnel). The whole plot factor consisted of the growing system type (i.e., high tunnel or field), the split-plot was PD and the splitsplit plot factor was cultivar. A cultivar comparison is not included in this article, but rather an average across all butterhead or romaine cultivars were evaluated. That said, the following cultivars were included in the study: 'Red Cross', 'Sylvesta', 'Adriana', 'Skyphos', 'Pirat', and 'Mirlo' for butterheads and 'Salvius', 'Coastal Star', 'Green Forest', 'Red Rosie', 'Super Jericho', and 'Freckles' for romaines. The experimental unit was 10 plants/plot. Lettuce seedlings were planted in two rows per bed, in a staggered arrangement with $31 \mathrm{~cm}$ between-rows and $25 \mathrm{~cm}$ within-rows.

Three PDs (i.e., early, mid, and late spring) were selected (Table 2) based on a local farmer's recommendations and by reviewing the previous 20 years of last spring frost dates at the project site which ranged from $28 \mathrm{Feb}$. to $16 \mathrm{Apr}$. The PDs were 3 weeks apart from each other. In 2015, the first PD was delayed by 1 week due to multiple rain events and the inability to prepare the field beds. Thus, PDs two and three were also delayed by 1 week. In 2016, the original PDs were implemented.

Systems management. Irrigation was usually applied every other day, although the interval varied depending on the current weather, soil moisture, and plant growth stage. There was one drip tape (Toro Microirrigation, El Cajon, CA) per row (i.e., two drip tapes per bed). In 2015, each irrigation cycle was 60 to $120 \mathrm{~min}$, and in 2016, the irrigation cycles were reduced to $60 \mathrm{~min}$ total to minimize soil surface moisture to help manage lettuce drop (S. sclerotiorum).

Table 1. Fertilizer and application rate applied to high tunnel and field systems in 2015 and 2016.

\begin{tabular}{llll}
\hline $\mathrm{Yr}$ & \multicolumn{1}{c}{ Fertilizer } & \multicolumn{1}{c}{ Analysis } & Application rate \\
\hline 2015 & Feathermeal $^{\mathrm{z}}$ & $(13 \mathrm{~N}-0 \mathrm{P}-0 \mathrm{~K})$ & $112 \mathrm{~kg} \mathrm{~N} / \mathrm{ha}$ \\
& $\mathrm{K}_{2} \mathrm{SO}_{4}{ }^{\mathrm{y}}$ & $(0 \mathrm{~N}-0 \mathrm{P}-41.5 \mathrm{~K})$ & $34 \mathrm{~kg} \mathrm{~K} / \mathrm{ha}$ \\
$2016^{\mathrm{w}}$ & Boron $^{\mathrm{x}}$ & $(10 \% \mathrm{~B})$ & $1 \mathrm{~kg} \mathrm{~B} / \mathrm{ha}$ \\
& Feathermeal & $(13 \mathrm{~N}-0 \mathrm{P}-0 \mathrm{~K})$ & $112 \mathrm{~kg} \mathrm{~N} / \mathrm{ha}$ \\
& $\mathrm{K}_{2} \mathrm{SO}_{4}$ (field only) & $(0 \mathrm{~N}-0 \mathrm{P}-41.5 \mathrm{~K})$ & $34 \mathrm{~kg} \mathrm{~K} / \mathrm{ha}$ \\
& Dolomitic lime $^{\mathrm{v}}$ (field only) & $(6 \% \mathrm{Mg})$ & $28 \mathrm{~kg} \mathrm{Mg} / \mathrm{ha}$ \\
& $\mathrm{MgSO}_{4}{ }^{u}$ (high tunnel only) & $(10 \% \mathrm{Mg} ; 13 \% \mathrm{~S})$ & $11 \mathrm{~kg} \mathrm{~S} / \mathrm{ha}$ \\
\hline
\end{tabular}

${ }^{\mathrm{z}}$ Mason City By-products Inc., Mason City, IA.

${ }^{\mathrm{y}} \mathrm{SQM}$ North America, Atlanta, GA.

${ }^{\mathrm{x}}$ Sun Coast, Sodus, MI.

${ }^{\mathrm{w}}$ In 2016, soil tests recommended adding S to both high tunnels and field but $\mathrm{K}$ and $\mathrm{Mg}$ to the high tunnels only.

vimerys Carbonates., Roswell, GA.

${ }^{\mathrm{u}}$ Rite Aide, Camp Hill, PA. 
Table 2. Seeding and transplanting dates in 2015 and 2016.

\begin{tabular}{lllr}
\hline Yr & $\begin{array}{c}\text { Planting } \\
\text { date }\end{array}$ & $\begin{array}{c}\text { Seeding } \\
\text { date }\end{array}$ & $\begin{array}{c}\text { Transplanting } \\
\text { date }\end{array}$ \\
\hline 2015 & PD1 $^{\mathrm{z}}$ & 29 Jan. & 12 Mar. \\
& PD2 & 19 Feb. & 2 Apr. \\
& PD3 & 12 Mar. & 23 Apr. \\
2016 & PD1 & 28 Jan. & 3 Mar. \\
& PD2 & 18 Feb. & 24 Mar. \\
& PD3 & 10 Mar. & 14 Apr. \\
\hline
\end{tabular}

${ }^{\mathrm{z}} \mathrm{PD}=$ planting date

Automatic drop-down side curtains were set to close at $10 \pm 1{ }^{\circ} \mathrm{C}$ and remained open when temperatures were $\geq 11^{\circ} \mathrm{C}$. Side curtains were closed when heavy rain or winds $\left(>24 \mathrm{~km} \cdot \mathrm{h}^{-1}\right)$ were predicted to protect plants from wind damage and to minimize water intrusion (i.e., roof runoff or rain blowing in through the sides). During warm periods (i.e., $\geq 11^{\circ} \mathrm{C}$ ) end walls were kept open as much as possible. When air temperatures were predicted to be $\leq 0{ }^{\circ} \mathrm{C}$, intermediate weight rowcovers $\left(18.6 \mathrm{~g} \cdot \mathrm{m}^{-1}\right)$ were used for frost protection in both the high tunnel and field systems. Row covers were draped over ninegauge galvanized wire hoops spaced every $1.8 \mathrm{~m}$ and edges held in place with weighted sand bags. The hoops were $\approx 0.5 \mathrm{~m}$ above the soil line at their apex. Weeding was done several times throughout the growing period with hand tools in both systems.

Environmental monitoring. Environmental monitoring stations were located in each high tunnel and field replication (Em50 Digital/Analog Data Logger; Decagon Devices Inc, Pullman, WA). Each station included sensors to measure air temperature and RH (VP-3; Decagon Devices Inc), photosynthetically active radiation (Measures PPF) (QSO-S PAR Photon Flux; Apogee Instruments, Logan, UT), soil temperature (5TM; Decagon Devices Inc), and leaf wetness counts (LWC) (LWS; Decagon Devices Inc). The air temperature and $\mathrm{RH}$ probes were placed inside radiation shields provided by the manufacturer. Average values for each parameter were recorded at hourly intervals. Using these hourly values, daily average, daily maximum, and daily minimum levels were calculated; each 24 -h period was defined as 7:00 to 6:00 AM. Soil temperature sensors were located $20 \mathrm{~cm}$ away from metal $t$-posts and at a depth of 10 to $16 \mathrm{~cm}$ from the soil surface. Light sensors, air temperature sensors, and leaf wetness sensors were placed 53, 46, and $31 \mathrm{~cm}$ above the soil line, respectively. Leaf wetness sensors were mounted at a $45^{\circ}$ angle. Environmental monitoring stations were located within experimental beds; they were covered with rowcovers along with plants on nights when temperatures were predicted to be $<0{ }^{\circ} \mathrm{C}$.

Pest and disease management. Integrated pest management (IPM) scouting was carried out twice each week. In 2015, fire ants (Solenopsis spp.), aphids (Aphidoidea spp.), and armyworms (Spodoptera exigua) were the major insect pests along with lettuce drop disease (S. sclerotiorum). Two spinosad-based products were used to manage fire ants in- cluding "Entrust SC" naturalyte insect control (Dow Agro Sciences, Indianapolis, IN) and "Come and get it" fire ant killer bait (Fertilome, Bonham, TX); Bacillus thuringiensis (DiPel DF; Valent USA Cooperation, Walnut Creek, CA) was used once to manage armyworms. It should be noted that "Come and get it" no longer maintains an Organic Materials Review Institute (OMRI) certification and may not be allowed in certified organic systems. In 2016, a biological fungicide containing Coniothyrium minitans (Contans WG; Sipcam Agro USA, Inc., Durham, NC) was applied to the surface of raised beds in both systems, at a rate of $2.3 \mathrm{~kg} \cdot \mathrm{ha}^{-1}$ as a soil drench at transplanting, to reduce the incidence of lettuce drop. All products were administered at recommended label rates.

Plants infected with lettuce drop were removed along with the surrounding surface soil and visible sclerotia, and disposed of in the trash. Dead or severely damaged plants, generally from fire ants or lettuce drop, were recorded and replaced up to 2 weeks from their original transplanting date. After 2 weeks, plants that died were not replaced.

Harvesting protocols. All plots were assessed two times per week. Plots were harvested when $>75 \%$ of the plants were judged to have firm, mature, marketable size heads or when $>25 \%$ of plants demonstrated signs of bolting, tip burn, or other defects. Judgments about marketable size were made from comparisons with lettuce for sale at local farmers markets and grocery stores. The number and weight of unwashed marketable and nonmarketable heads from each butterhead and romaine lettuce plot were recorded. The number of bolted (premature flowering) plants, plants with tip-burn, and undersized heads/no-closed head formation were also recorded as nonmarketable.

Statistical analysis. The main factors of comparison were two production systems (i.e., high tunnel vs. field) and three PDs (i.e., early, mid, and late). A set of analyses to assess microenvironment differences were completed. Continuous response variables included air temperature, soil temperature, $\mathrm{RH}$, LWC, and photosynthetic photon flux $(P P F)$. The daily light integral (DLI) was calculated from the $P P F$. The aforementioned variables were all about normally distributed, so the statistical analysis was carried out using a mixed effects analysis of variance (ANOVA) model (SAS v. 9.4; SAS Institute, Cary, NC). These variables were not transformed. Tukey's mean separation method with $95 \%$ confidence level was used to determine significant differences between the two production system types or three PDs. Each year was analyzed separately to account for different weather patterns. Nonsignificant interactions were dropped from the models. Statistical analysis was not conducted on average; monthly results presented in Table 3. These averages were presented only to generalize comparisons between years and between early to late spring at our research site and to other studies.

A similar set of analyses were completed to assess yield differences. The three contin- uous response variables included were marketable yield per plot, individual marketable head weight, and days to harvest. Individual marketable head fresh weight was obtained by dividing the number of marketable heads by the total marketable yield per plot. Variables were all about normally distributed, so the statistical analysis was carried out using a mixed effects ANOVA model (SAS v. 9.4; SAS Institute). Tukey's mean separation method with $95 \%$ confidence level was used to determine significant differences between production systems or PDs. Each year was analyzed separately to account for different weather patterns. Also, butterhead and romaine lettuce data were analyzed separately to allow for a comparison of these two lettuce types. Thus, in all, there were 12 analyses conducted each year including two production systems, three PDs, and two lettuce types.

The response variables related to nonmarketable yield categories, made up of small positive integers were analyzed differently because they were not continuous variables. This included percent nonmarketable, physiological defect categories (i.e., bolting, tip burn, and undersized heads) and percent dead plants due to $S$. sclerotiorum infection. Each variable was analyzed separately with a logistic regression model to predict a proportion of the total harvested heads that were nonmarketable using system type and PD as explanatory variables (SAS v. 9.4, SAS Institute). Each year was analyzed separately to account for different weather patterns. Also, butterhead and romaine lettuce data were analyzed separately to allow for comparisons of each lettuce type.

\section{Results}

Microclimate. During the growing seasons, the daily average air temperatures were 0.5 to $1.6{ }^{\circ} \mathrm{C}$ greater under high tunnels compared with the field (Fig. 1) $(P<$ $0.0001)$. On the coldest nights of the experiment (29 Mar. 2015 and 22 Mar. 2016), the high tunnels were 3 to $5{ }^{\circ} \mathrm{C}$ warmer than the field (Fig. 1). On the warmest afternoons (7 June 2015 and 31 May 2016), the high tunnels were 1.0 to $1.3{ }^{\circ} \mathrm{C}$ warmer than the field (Fig. 1). Daily air temperature fluctuations of 11 to $16^{\circ} \mathrm{C}$ (i.e., difference between daily max and min temperatures) were common over the spring season under the high tunnels (Table 3 ). In both years, the average and minimum daily soil temperatures were greater under high tunnels $\left(1.2\right.$ to $\left.1.3{ }^{\circ} \mathrm{C}\right)$ compared with the field, whereas the average daily minimum soil temperature was $\approx 2.0^{\circ} \mathrm{C}$ greater under high tunnels compared with the field $(P=0.0015)$

In 2015 and 2016, the high tunnels had greater minimum, average, and maximum daily air temperatures compared with the field for all three PDs $(P<0.0057)$ (Table 4). Both years, the high tunnels had greater minimum and average daily soil temperatures compared with the field for all three PDs except PD3 in $2016(P<0.0271)$ (Table 4). 
Table 3. Average monthly microenvironmental data in high tunnel (HT) and field (F) systems.

\begin{tabular}{|c|c|c|c|c|c|c|c|c|c|c|c|}
\hline \multirow[b]{2}{*}{$\mathrm{Yr}$} & \multirow[b]{2}{*}{ Mo. } & \multirow[b]{2}{*}{ System } & \multicolumn{3}{|c|}{ Air temp. $\left({ }^{\circ} \mathrm{C}\right)$} & \multicolumn{3}{|c|}{ Soil temp. $\left({ }^{\circ} \mathrm{C}\right)$} & \multirow{2}{*}{$\frac{\mathrm{RH} \%}{\text { Mean }}$} & \multirow{2}{*}{$\frac{\operatorname{DLI}^{\mathrm{z}}\left(\mathrm{mol} \cdot \mathrm{m}^{-2} \cdot \mathrm{d}^{-1}\right)}{\text { Mean }}$} & \multirow{2}{*}{$\frac{\mathrm{LWC}^{\mathrm{y}}\left(\mathrm{min} \cdot \mathrm{d}^{-1}\right)}{\text { Mean }}$} \\
\hline & & & Min & Mean & $\operatorname{Max}$ & Min & Mean & $\operatorname{Max}$ & & & \\
\hline \multirow[t]{8}{*}{2015} & $\operatorname{March}^{x}$ & $\mathrm{HT}$ & 8.7 & 15.1 & 21.8 & 14.9 & 17.2 & 19.6 & 73.2 & 21.0 & 5 \\
\hline & & $\mathrm{F}$ & 6.8 & 13.9 & 20.4 & 11.5 & 14.8 & 18.1 & 74.2 & 30.3 & 623 \\
\hline & April & HT & 12.4 & 18.5 & 24.5 & 18.0 & 20.2 & 22.3 & 74.7 & 23.0 & 2 \\
\hline & & $\mathrm{F}$ & 11.8 & 18.0 & 23.7 & 15.8 & 18.7 & 21.5 & 76.8 & 33.0 & 580 \\
\hline & May & HT & 15.0 & 22.6 & 30.4 & 22.3 & 25.2 & 28.3 & 71.0 & 33.1 & 9 \\
\hline & & $\mathrm{F}$ & 14.3 & 22.0 & 29.7 & 20.6 & 24.7 & 29.2 & 72.8 & 49.8 & 473 \\
\hline & June $^{\mathrm{w}}$ & HT & 19.0 & 24.2 & 31.2 & 24.7 & 27.3 & 30.5 & 79.7 & 30.2 & 33 \\
\hline & & $\mathrm{F}$ & 18.5 & 23.4 & 30.1 & 22.2 & 26.0 & 30.7 & 82.8 & 45.0 & 628 \\
\hline \multirow[t]{8}{*}{2016} & $\operatorname{March}^{v}$ & HT & 8.4 & 16.1 & 23.0 & 15.9 & 18.5 & 20.9 & 69.2 & 23.0 & 54 \\
\hline & & $\mathrm{F}$ & 6.8 & 15.1 & 22.0 & 12.8 & 16.1 & 19.1 & 70.8 & 35.7 & 437 \\
\hline & April & HT & 10.5 & 17.8 & 25.1 & 18.0 & 20.4 & 22.7 & 65.4 & 26.4 & 10 \\
\hline & & $\mathrm{F}$ & 8.9 & 16.9 & 24.0 & 16.0 & 19.1 & 21.8 & 67.2 & 44.9 & 401 \\
\hline & May & HT & 14.2 & 21.6 & 28.5 & 21.4 & 23.7 & 25.8 & 67.2 & 27.3 & 35 \\
\hline & & $\mathrm{F}$ & 13.6 & 21.0 & 27.6 & 20.1 & 23.5 & 26.7 & 68.3 & 47.0 & 232 \\
\hline & June $^{\mathrm{u}}$ & HT & 19.0 & 25.8 & 33.3 & 25.7 & 28.3 & 30.9 & 69.8 & 28.8 & 24 \\
\hline & & $\mathrm{F}$ & 18.4 & 24.9 & 31.8 & 23.8 & 27.3 & 30.9 & 72.3 & 48.3 & 362 \\
\hline
\end{tabular}

$\mathrm{RH}=$ relative humidity.

${ }^{\mathrm{z} D L I}$ (daily light integral) = the amount of photosynthetically active radiation received per day.

${ }^{\mathrm{y}} \mathrm{LWC}=$ leaf wetness counts.

x 12 Mar. 2015 to 1 Apr. 2015.

w1 June 2015 to 12 June 2015.

v3 Mar. 2016 to 1 Apr. 2016.

$\mathrm{u}_{1}$ June 2016 to 10 June 2016.

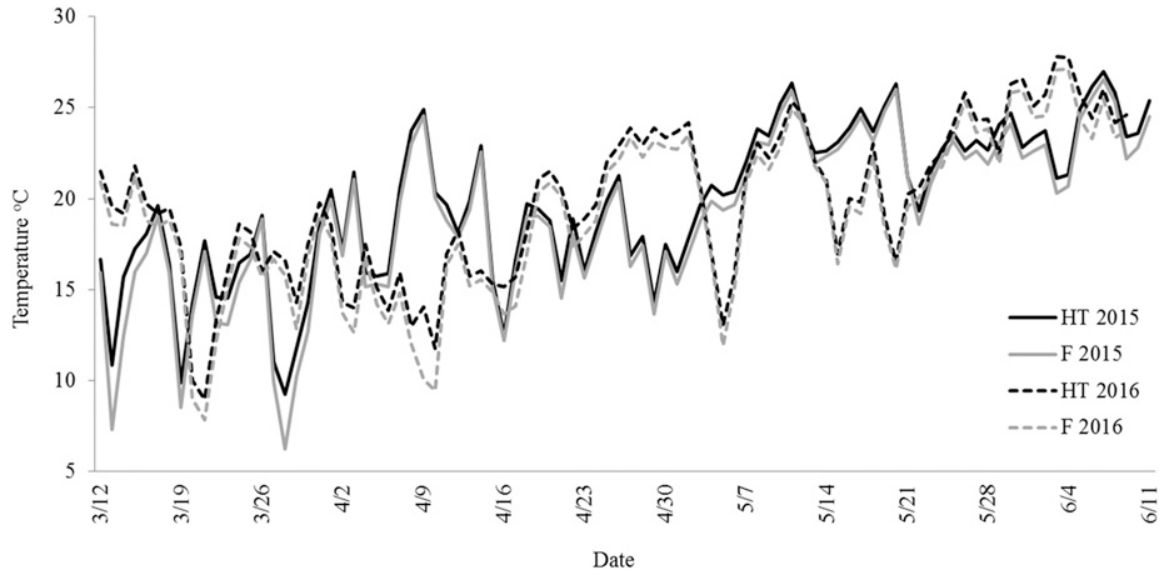

Fig. 1. Daily average air temperatures in high tunnel (HT) and field (F) systems in 2015 and 2016.

Maximum soil temperature was not significantly different between the high tunnels and the field among PDs (Table 4).

The amount of rainfall recorded was $\approx 50 \%$ greater in 2015 (328 mm) compared with 2016 (169 $\mathrm{mm}$ ) according to the University of Georgia Automated Environmental Weather Network (http://www.georgiaweather.net/) monitoring station located $<0.5 \mathrm{~km}$ from the experimental site (UGA Horticulture Research Farm, Oconee County, GA) (data not shown). The rainfall pattern was reflected by the average LWC being greater in 2015 compared with 2016 (Table 3). In March of 2015, the high tunnel system had a negligible amount of time per day with leaf wetness compared with $623 \mathrm{~min} \cdot \mathrm{d}^{-1}$ in the field (Table 3 ). Both years, the average daily $\mathrm{RH}$ was $\approx 2 \%$ lower under the high tunnels compared with the field $(P=$ 0.0006 ) (Table 3 ). The average monthly DLI ranged from $\approx 20$ to $50 \mathrm{~mol} \cdot \mathrm{m}^{-2} \cdot \mathrm{d}^{-1}$ (Table 3 ). The average daily DLI ranged from 10 to 60 $\mathrm{mol} \cdot \mathrm{m}^{-2} \cdot \mathrm{d}^{-1}$ over the growing season (Table 3 ). The average DLI was $32 \%$ to $40 \%$ lower under our high tunnel system compared with the field $(P<0.0001)$.
Yield. The total marketable fresh weight of butterhead or romaine lettuce was not significantly different between the high tunnels and the field in 2015, but it was in 2016 . In 2016 , the butterhead yield was $25 \%$ greater and the romaine yield $36 \%$ greater than the field $(P<0.0392)$ (Tables 5 and 6$)$. The individual fresh weight of a lettuce head was primarily responsible for these gains in 2016 (Tables 5 and 6). In 2015, no difference was observed in the average length or diameter of butterhead or romaine lettuce, but both were greater in 2016 under high tunnels compared with the field (data not shown). In 2015, the days to harvest was 2 to $3 \mathrm{~d}$ earlier for butterhead and romaine lettuce under high tunnels compared with the field, although the difference was not significant. In 2016, butterhead and romaine lettuce were ready to harvest $\approx 7 \mathrm{~d}$ earlier under high tunnels compared with the field $(P=0.0207)$ (Tables 5 and 6).

In 2015, no difference was observed in marketable fresh weight of butterhead or romaine lettuce among the three PDs (Table 7). However, in 2016, both lettuce types had greater marketable fresh weights for PD1 compared with PD2 and PD3 $(P \leq$ 0.0001 ) (Table 7). The inner stem length of romaine lettuce was not significantly different among the PDs (data not shown). In 2015, the average number of days to harvest for butterhead and romaine lettuce was greater for PD1 compared with PD2 which was greater than PD3. In 2016, the average number of days to harvest followed the same trends as 2015 (Table 7). No significant interactions between the system and PD were present in 2015 but in 2016, both butterhead and romaine lettuce had a greater marketable fresh weight for PD1 and PD2 under the high tunnels compared with the field $(P<0.0191)$ (Table 7).

Nonmarketable categories. In 2015, 3.5\% of high tunnel butterhead lettuce and $0.7 \%$ of field butterhead lettuce were categorized as nonmarketable due to bolting and in 2016 it was $\approx 1.0 \%$ for each growing system (Table 5). In $2015,13 \%$ to $14 \%$ of romaine lettuce was categorized as nonmarketable due to bolting in both growing systems, but in 2016 , the amount decreased to $\approx 5 \%$ in the high tunnels and $11 \%$ in the field (Table 6). The romaine cultivar 'Freckles' accounted for $75 \%$ to $89 \%$ of the bolting incidence in 2015 and 2016, respectively (data not shown). In 2015, the percentage of tip burn of butterhead lettuce was $\approx 6 \%$ in the high tunnels and $<1 \%$ in the field. In 2016, the percentage of tip burn for butterheads was $5 \%$ in the tunnels, whereas none was observed in the field (Table 5). In both years, $\approx 9 \%$ to $10 \%$ of the romaine plants displayed tip burn in the high tunnels and $2 \%$ to $3 \%$ in the field (Table 6).

In 2015, the percentage of total nonmarketable lettuce was not different for either butterhead or romaine lettuce among PDs. However, in 2016, the percentage of nonmarketable lettuce was greater for PD3 compared with PD1 and PD2 for both butterhead 
Table 4. Microenvironmental data among three spring planting dates (PDs).

\begin{tabular}{|c|c|c|c|c|c|c|c|c|c|}
\hline \multirow[b]{2}{*}{$\mathrm{Yr}$} & \multirow[b]{2}{*}{ PD } & \multirow[b]{2}{*}{ System } & \multicolumn{3}{|c|}{ Air temp. $\left({ }^{\circ} \mathrm{C}\right)$} & \multicolumn{3}{|c|}{ Soil temp. $\left({ }^{\circ} \mathrm{C}\right)$} & \multirow{2}{*}{$\frac{\text { RH \% }}{\text { Mean }}$} \\
\hline & & & Min & Mean & Max & Min & Mean & Max & \\
\hline \multirow[t]{6}{*}{$2015^{z}$} & PD1 & HT & $11.7 \mathrm{a}^{\mathrm{y}}$ & $18.4 \mathrm{a}$ & $25.2 \mathrm{a}$ & $17.9 \mathrm{a}$ & $20.4 \mathrm{a}$ & $22.9 \mathrm{a}$ & $72.5 \mathrm{a}$ \\
\hline & & $\mathrm{F}$ & $10.7 \mathrm{~b}$ & $17.7 \mathrm{~b}$ & $24.2 \mathrm{~b}$ & $15.5 \mathrm{~b}$ & $18.9 \mathrm{~b}$ & $22.3 \mathrm{a}$ & $74.2 \mathrm{~b}$ \\
\hline & PD2 & HT & $13.2 \mathrm{a}$ & $20.2 \mathrm{a}$ & $27.1 \mathrm{a}$ & $19.8 \mathrm{a}$ & $22.4 \mathrm{a}$ & $24.9 \mathrm{a}$ & $71.9 \mathrm{a}$ \\
\hline & & $\mathrm{F}$ & $12.5 \mathrm{~b}$ & $19.7 \mathrm{~b}$ & $26.4 \mathrm{~b}$ & $17.8 \mathrm{~b}$ & $21.3 \mathrm{~b}$ & $24.9 \mathrm{a}$ & $73.8 \mathrm{~b}$ \\
\hline & PD3 & HT & $14.9 \mathrm{a}$ & $22.1 \mathrm{a}$ & $29.5 \mathrm{a}$ & $22.0 \mathrm{a}$ & $24.8 \mathrm{a}$ & $27.7 \mathrm{a}$ & $72.0 \mathrm{a}$ \\
\hline & & $\mathrm{F}$ & $14.3 \mathrm{~b}$ & $21.5 \mathrm{~b}$ & $28.8 \mathrm{~b}$ & $20.1 \mathrm{~b}$ & $23.9 \mathrm{~b}$ & $28.2 \mathrm{a}$ & $74.1 \mathrm{~b}$ \\
\hline \multirow[t]{6}{*}{$2016^{z}$} & PD1 & HT & $10.0 \mathrm{~A}$ & $17.5 \mathrm{~A}$ & $24.7 \mathrm{~A}$ & $17.5 \mathrm{~A}$ & $19.9 \mathrm{~A}$ & $22.2 \mathrm{~A}$ & $67.2 \mathrm{~A}$ \\
\hline & & $\mathrm{F}$ & $8.5 \mathrm{~B}$ & $16.6 \mathrm{~B}$ & $23.6 \mathrm{~B}$ & $15.1 \mathrm{~B}$ & $18.3 \mathrm{~B}$ & $21.3 \mathrm{~A}$ & $68.8 \mathrm{~B}$ \\
\hline & PD2 & HT & $11.7 \mathrm{~A}$ & $18.9 \mathrm{~A}$ & $25.8 \mathrm{~A}$ & $19.0 \mathrm{~A}$ & $21.3 \mathrm{~A}$ & $23.4 \mathrm{~A}$ & $68.0 \mathrm{~A}$ \\
\hline & & $\mathrm{F}$ & $10.6 \mathrm{~B}$ & $18.1 \mathrm{~B}$ & $24.7 \mathrm{~B}$ & 17.2 B & $20.3 \mathrm{~B}$ & $23.2 \mathrm{~A}$ & $69.5 \mathrm{~B}$ \\
\hline & PD3 & HT & $14.3 \mathrm{~A}$ & $21.8 \mathrm{~A}$ & $29.1 \mathrm{~A}$ & $21.6 \mathrm{~A}$ & $24.0 \mathrm{~A}$ & $26.2 \mathrm{~A}$ & $67.3 \mathrm{~A}$ \\
\hline & & $\mathrm{F}$ & $13.5 \mathrm{~B}$ & $21.1 \mathrm{~B}$ & $28.1 \mathrm{~B}$ & $20.1 \mathrm{~B}$ & $23.5 \mathrm{~A}$ & $26.7 \mathrm{~A}$ & $68.8 \mathrm{~B}$ \\
\hline
\end{tabular}

${ }^{\mathrm{z}}$ Each year was analyzed separately as indicated by the different sized letters.

${ }^{\mathrm{y}}$ Values followed by the same letter are not significantly different within a column for each year, according to Tukey's mean separation test $(P \leq 0.05)$.

Table 5. Mean butterhead lettuce yields and days to harvest between the high tunnel and field systems.

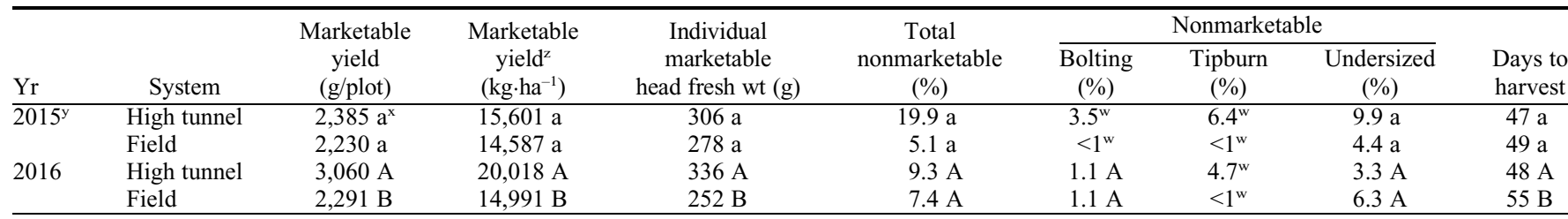

${ }_{\mathrm{z}}^{\mathrm{T}}$ The yield per hectare was estimated based on plot yields and estimate that $65 \%$ of the total land area was planted with a crop in high tunnel and field which was representative of our experimental planting design.

${ }^{\mathrm{y}}$ Each year was analyzed separately as indicated by the different sized letters.

${ }^{\mathrm{x}}$ Values followed by the same letter are not significantly different within a column for each year, according to Tukey's mean separation test $(P \leq 0.05)$.

${ }^{\mathrm{w}}$ Not analyzed because of too few data points.

and romaine (Table 7). For 2016 romaine lettuce, the percentage of plants that bolted was greater for PD3 (17\%) compared with PD1 (2\%) and PD2 (6\%).

Disease incidence. In $2015, \approx 6 \%$ of high tunnel and $11 \%$ of the field-grown butterhead crop died due to lettuce drop infection. In $2016, \approx 1 \%$ of butterhead lettuce plants died in each growing system (Table 5). There were no differences between lettuce drop incidence for butterheads among growing systems and PDs in either year. In 2015, $\approx 9 \%$ of high tunnel and $10 \%$ of field romaine plants died from lettuce drop (Table 6). In 2016, 4\% of high tunnel and $2 \%$ of field romaine died due to lettuce drop (Table 6). In 2015, the percentage of lettuce drop incidence in romaine lettuce was greater for PD1 compared with PD3 $(P=0.0455)$, but there were no differences between growing systems (Table 7). In 2016, no differences in lettuce drop incidence were observed among growing systems and PDs for the romaine crop.

\section{Discussion}

A greater marketable fresh weight for both butterhead and romaine lettuce was observed under high tunnels compared with the field in 2016 but not in 2015 . Over the same period, the marketability of the crop (i.e., lettuce quality) was similar for both systems. These results suggest that high tunnels can help increase the production potential of spring organic lettuce yield in Georgia; however, this advantage may depend on yearly weather conditions. Other high tunnel studies have found similar in- creases in crop yields depending on the yearly weather characteristics (O'Connell et al., 2012; Wallace et al., 2012). A season extension benefit was also gained from the high tunnels. Overall, high tunnel lettuce was ready to harvest 2 to $7 \mathrm{~d}$ earlier than the field, in 2015 and 2016, respectively. These results are in relative agreement with a similar lettuce study which found that high tunnel lettuce was harvested $\approx 1$ to 2 weeks earlier (Wallace et al., 2012).

Lettuce drop was the only disease that caused significant damage to the crop. The percentage of plants that died due to lettuce drop was not statistically different between the high tunnel and field systems either year, indicating that high tunnels did not provide additional protection from this disease. Although the duration of leaf wetness under the high tunnels was lower than in the field, the incidence of lettuce drop did not have a positive or predictive relationship with LWC. This is may be because both RH and leaf wetness can influence the production and transport of fungal inoculum to the susceptible lettuce crown (Huber and Gillespie, 1992).

The percentage of lettuce plants infected by lettuce drop was greater in 2015 compared with 2016 and earlier PDs in 2015 appeared more susceptible to infection. Clarkson et al. (2014) noted that lettuce drop infection increases rapidly between 16 and $27^{\circ} \mathrm{C}$ degrees and $70 \%$ to $100 \%$ RH. In 2015 , both the average temperature and RH were within these ranges in both the high tunnels and field, but in 2016 the RH was lower than this range. Therefore, monitoring $\mathrm{RH}$, soil surface moisture, or moisture at the lettuce crown may be more useful to predict disease outbreaks and explore alternative management techniques for high tunnel systems than leaf wetness.

Results suggest that disease incidence was lower in 2016 due to lower RH but we also reduced the length of irrigation cycles to maintain a drier soil surface and applied a parasitic fungus (Coniothyrium minitans) before transplanting lettuce the second season. These actions may have contributed to the reduced disease pressure in 2016. The effectiveness of $C$. minitans requires both time and placement in close proximity to the pathogen. One controlled C. minitans efficacy study found a $35 \%$ reduction in the incidence of $S$. sclerotiorum on lettuce (Chitrampalam et al., 2010). Another study, investigating biological control agents for $S$. sclerotiorum on soybean found that $C$. minitans reduced disease severity by $69 \%$ and the number of sclerotia by $95 \%$ (Zeng et al., 2012). Because of the wide host range of $S$. sclerotiorum including many high-value horticultural crops, future investigations into the efficacy of $C$. minitans under high tunnel systems may be a valuable pursuit in regions susceptible to the disease.

Overall, spring high tunnel air temperatures were an average of 0.5 to $1.6^{\circ} \mathrm{C}$ greater than the field. On the coldest mornings of the experiment, high tunnels maintained temperatures 3 to $5{ }^{\circ} \mathrm{C}$ greater than the field illustrating their ability to mitigate cold temperatures. On the warmest afternoons during the experiment, high tunnels were only $\approx 1.0^{\circ} \mathrm{C}$ greater than the field. These results challenge the assertion that high tunnel systems are much hotter than the field 
Table 6. Mean romaine lettuce yields and days to harvest between the high tunnel and field systems.

\begin{tabular}{|c|c|c|c|c|c|c|c|c|c|}
\hline \multirow[b]{2}{*}{ Yr } & \multirow[b]{2}{*}{ System } & \multirow[b]{2}{*}{$\begin{array}{c}\text { Marketable } \\
\text { yield (g/plot) }\end{array}$} & \multirow{2}{*}{$\begin{array}{c}\text { Marketable } \\
\text { yield } \\
\left(\mathrm{kg} \cdot \mathrm{ha}^{-1}\right)\end{array}$} & \multirow{2}{*}{$\begin{array}{c}\text { Individual } \\
\text { marketable } \\
\text { head fresh wt }(\mathrm{g})\end{array}$} & \multirow{2}{*}{$\begin{array}{c}\text { Total } \\
\text { nonmarketable } \\
(\%)\end{array}$} & \multicolumn{3}{|c|}{ Nonmarketable } & \multirow[b]{2}{*}{$\begin{array}{l}\text { Days to } \\
\text { harvest }\end{array}$} \\
\hline & & & & & & $\begin{array}{c}\text { Bolting } \\
(\%)\end{array}$ & $\begin{array}{l}\text { Tipburn } \\
(\%)\end{array}$ & $\begin{array}{c}\text { Undersized } \\
(\%)\end{array}$ & \\
\hline \multirow[t]{2}{*}{$2015^{y}$} & High tunnel & $2,138 \mathrm{a}^{\mathrm{x}}$ & $13,984 \mathrm{a}$ & $418 \mathrm{a}$ & $35.5 \mathrm{a}$ & $14.3 \mathrm{a}$ & $8.9 \mathrm{a}$ & $12.3 \mathrm{a}$ & $48 \mathrm{a}$ \\
\hline & Field & $2,236 \mathrm{a}$ & $14,626 \mathrm{a}$ & $446 \mathrm{a}$ & $35.2 \mathrm{a}$ & $12.5 \mathrm{a}$ & $2.8 \mathrm{a}$ & $19.9 \mathrm{a}$ & $52 \mathrm{a}$ \\
\hline \multirow[t]{2}{*}{2016} & High tunnel & $3,434 \mathrm{~A}$ & $22,468 \mathrm{~A}$ & $418 \mathrm{~A}$ & $17.5 \mathrm{~A}$ & $5.2 \mathrm{~A}$ & $10.0 \mathrm{~A}$ & $2.4 \mathrm{~A}$ & $50 \mathrm{~A}$ \\
\hline & Field & $2,202 \mathrm{~B}$ & $14,403 \mathrm{~B}$ & $283 \mathrm{~B}$ & $19.2 \mathrm{~A}$ & $10.8 \mathrm{~A}$ & $1.5 \mathrm{~A}$ & $6.9 \mathrm{~A}$ & $57 \mathrm{~B}$ \\
\hline
\end{tabular}

${ }^{\mathrm{z}}$ The yield per hectare was estimated based on plot yields and estimate that $65 \%$ of the total land area was planted with a crop in high tunnels and field which was representative of our experimental planting design.

${ }^{y}$ Each year was analyzed separately as indicated by the different sized letters.

${ }^{\mathrm{x}}$ Values followed by the same letter are not significantly different within a column for each year, according to Tukey's mean separation test $(P \leq 0.05)$.

Table 7. Mean butterhead and romaine lettuce yields, days to harvest, and disease incidence among three spring planting dates (PDs).

\begin{tabular}{|c|c|c|c|c|c|c|c|c|c|c|c|}
\hline \multirow[b]{2}{*}{ Type } & \multirow[b]{2}{*}{ Yr } & \multirow[b]{2}{*}{ PD } & \multirow[b]{2}{*}{$\begin{array}{c}\text { Marketable } \\
\text { yield (g/plot) }\end{array}$} & \multirow{2}{*}{$\begin{array}{c}\text { Marketable } \\
\text { yield }^{z} \\
\left(\mathrm{~kg} \cdot \mathrm{ha}^{-1}\right)\end{array}$} & \multirow{2}{*}{$\begin{array}{c}\text { Individual } \\
\text { marketable } \\
\text { head fresh wt }(\mathrm{g})\end{array}$} & \multirow{2}{*}{$\begin{array}{c}\text { Total } \\
\text { nonmarketable } \\
(\%)\end{array}$} & \multicolumn{3}{|c|}{ Nonmarketable } & \multirow[b]{2}{*}{$\begin{array}{c}\text { Disease } \\
(\%)\end{array}$} & \multirow[b]{2}{*}{$\begin{array}{l}\text { Days to } \\
\text { harvest }\end{array}$} \\
\hline & & & & & & & $\begin{array}{c}\text { Bolting } \\
(\%)\end{array}$ & $\begin{array}{l}\text { Tipburn } \\
(\%)\end{array}$ & $\begin{array}{c}\text { Undersized } \\
(\%)\end{array}$ & & \\
\hline \multirow[t]{3}{*}{$\mathrm{BH}^{\mathrm{y}}$} & $2015^{x}$ & PD1 & $2,059 \mathrm{a}^{\mathrm{w}}$ & $13,466 \mathrm{a}$ & $310 \mathrm{a}$ & $13 \mathrm{a}$ & $0.6 \mathrm{a}$ & $0.6 \mathrm{a}$ & $12.4 \mathrm{a}$ & $18.2 \mathrm{a}$ & $56 \mathrm{a}$ \\
\hline & & PD2 & $2,760 \mathrm{a}$ & $18,050 \mathrm{a}$ & $327 \mathrm{a}$ & $11 \mathrm{a}$ & $4.2 \mathrm{a}$ & $3.1 \mathrm{a}$ & $2.1 \mathrm{a}$ & $6.9 \mathrm{a}$ & $46 \mathrm{~b}$ \\
\hline & & PD3 & $2,103 \mathrm{a}$ & $13,754 \mathrm{a}$ & $240 \mathrm{~b}$ & $12 \mathrm{a}$ & $1.5 \mathrm{a}$ & $5.2 \mathrm{a}$ & $5.2 \mathrm{a}$ & $0.8 \mathrm{a}$ & $42 \mathrm{c}$ \\
\hline \multirow[t]{3}{*}{$\mathrm{BH}$} & 2016 & PD1 & $3,437 \mathrm{~A}$ & $22,478 \mathrm{~A}$ & $364 \mathrm{~A}$ & $3 \mathrm{~A}$ & $<1^{\mathrm{v}}$ & $<1^{\mathrm{v}}$ & $2.5 \mathrm{~A}$ & $2.3 \mathrm{~A}$ & $55 \mathrm{~A}$ \\
\hline & & PD2 & $2,472 \mathrm{~B}$ & $16,167 \mathrm{~B}$ & $264 \mathrm{~B}$ & $3 \mathrm{~A}$ & $<1^{\mathrm{v}}$ & $0.1^{\mathrm{v}}$ & $2.5 \mathrm{~A}$ & $1.7 \mathrm{~A}$ & $51 \mathrm{AB}$ \\
\hline & & PD3 & $2,118 \mathrm{~B}$ & $13,852 \mathrm{~B}$ & $255 \mathrm{~B}$ & $19 \mathrm{~B}$ & $3.4^{\mathrm{v}}$ & $6.3^{\mathrm{v}}$ & $9.4 \mathrm{~A}$ & $0.2 \mathrm{~A}$ & $49 \mathrm{~B}$ \\
\hline \multirow[t]{3}{*}{$\mathrm{RM}^{\mathrm{u}}$} & 2015 & PD1 & $2,218 \mathrm{a}$ & $14,506 \mathrm{a}$ & $561 \mathrm{a}$ & $34 \mathrm{a}$ & $6.5 \mathrm{a}$ & $10.3 \mathrm{a}$ & $16.9 \mathrm{a}$ & $21.0 \mathrm{a}$ & $59 \mathrm{a}$ \\
\hline & & PD2 & $1,595 \mathrm{a}$ & 10,431 a & $347 \mathrm{~b}$ & $45 \mathrm{a}$ & $18.5 \mathrm{a}$ & $3.1 \mathrm{a}$ & $23.1 \mathrm{a}$ & $6.2 \mathrm{ab}$ & $49 \mathrm{~b}$ \\
\hline & & PD3 & $2,747 \mathrm{a}$ & $17,965 \mathrm{a}$ & $387 \mathrm{~b}$ & $27 \mathrm{a}$ & $14.7 \mathrm{a}$ & $4.2 \mathrm{a}$ & $8.2 \mathrm{~b}$ & $1.5 \mathrm{~b}$ & $42 \mathrm{c}$ \\
\hline \multirow[t]{3}{*}{$\mathrm{RM}$} & 2016 & PD1 & $3,860 \mathrm{~A}$ & $25,244 \mathrm{~A}$ & $447 \mathrm{~A}$ & $11 \mathrm{~A}$ & $1.5 \mathrm{~A}$ & $5.4 \mathrm{~A}$ & $4.2 \mathrm{~A}$ & $3.6 \mathrm{~A}$ & $61 \mathrm{~A}$ \\
\hline & & PD2 & $2,540 \mathrm{~B}$ & $16,612 \mathrm{~B}$ & $310 \mathrm{~B}$ & $15 \mathrm{~A}$ & $5.9 \mathrm{~A}$ & $6.4 \mathrm{~A}$ & $2.5 \mathrm{~A}$ & $3.8 \mathrm{~A}$ & $54 \mathrm{~B}$ \\
\hline & & PD3 & $2,054 \mathrm{~B}$ & $13,433 \mathrm{~B}$ & 294 B & $29 \mathrm{~B}$ & $16.6 \mathrm{~B}$ & $5.5 \mathrm{~A}$ & $7.1 \mathrm{~A}$ & $1.7 \mathrm{~A}$ & $46 \mathrm{C}$ \\
\hline
\end{tabular}

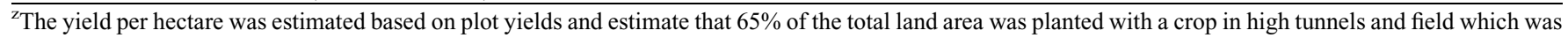
representative of our experimental planting design.

${ }^{\mathrm{y}} \mathrm{BH}=$ butterhead lettuce.

${ }^{\mathrm{x}}$ Each year was analyzed separately as indicated by the different sized letters.

${ }^{\text {w}}$ Values followed by the same letter are not significantly different within a column for each year, according to Tukey's mean separation test $(P \leq 0.05)$.

${ }^{v}$ Not analyzed because of too few data points.

${ }^{\mathrm{u}} \mathrm{RM}=$ romaine lettuce.

on warm, sunny days. The similarities between our high tunnel and field systems may be because air temperature sensors were at the height of lettuce crop canopy which may be cooler than taller points under the high tunnel. Also, our high tunnels had $1.83 \mathrm{~m}$ tall side walls and a 4.9-m wide end wall opening to maximize the ventilation capacity. High tunnel management protocols emphasized opening side walls and end walls on warm, sunny days to maximize the cross-flow ventilation. Attention to high tunnel design and orientation to encourage natural ventilation capacity may be a critical for regions subject to many warm and sunny days.

Overall, RH under the high tunnels was $\approx 2 \%$ lower than the field. This may be due to the slightly warmer high tunnel air temperatures which could hold more moisture compared with the field. This result is similar to a study in the Midwestern region that indicated high tunnels did not cause a marked change in $\mathrm{RH}$ compared with the field (Zhao and Carey, 2009).

During the growing season, the average DLI in the field was within the mean normal range (i.e., last 30 years) for the region (Korczynski et al., 2002) yet the it was reduced by $32 \%$ and $40 \%$ in the high tunnel system compared with the field in 2015 and 2016, respectively. The reduction of DLI level from 2015 to 2016 may have been a result of plastic degradation (i.e., physical damage, ultraviolet damage, dust). Nevertheless, the amount of DLI entering the high tunnels was consistently above the recommended minimum light levels for lettuce $\left(>15 \mathrm{~mol} \cdot \mathrm{m}^{-2} \cdot \mathrm{d}^{-1}\right)$ (Runkle, 2011). Borrelli et al. also noted a $27 \%$ to $36 \%$ reduction in light level with a single layer of $0.15 \mathrm{~mm}$ ultraviolettreated greenhouse plastic roof (2013).

No consistent differences were discernible among nonmarketable lettuce due to bolting or tip burn among high tunnel and field systems. This is in contrast to other studies that reported greater levels of bolting in high tunnels compared with field production (Wallace et al., 2012). Minimal differences in maximum air and soil temperatures between the two growing systems in our study may have contributed to a lack of differences in bolting or tip-burn in 2015. When comparing the three PDs in 2016, the last PD (PD3) did have a greater incidence of bolting compared with PD1 in both growing systems. This may be attributable to greater air and soil temperatures, longer photoperiod, or both associated with later PDs (i.e., early vs. late spring).

Although it appeared that romaine lettuce was more susceptible to both bolting than the butterhead type this difference was primarily due to one highly susceptible cultivar, 'Freckles'. And while not conclusive, results indicated that average night and daytime temperatures consistently exceed optimal lettuce crop production conditions during the month of May and June in our region.
Therefore, exploring the heat and humidity tolerance of different lettuce types as well as methods to cool high tunnel microenvironments would help optimize and extend the lettuce growing season to meet the local and organic market demand.

Later PDs resulted in a shorter crop cycle. In 2015 and 2016, the average number of days to harvest was 5-10 d longer for PD1 compared with PD3 for both the high tunnels and field. This is related to the increasing temperature, day-length or light intensity over the spring growing period which resulted in faster growth. A romaine lettuce study compared multiple PDs also indicated that lettuce grown during warmer parts of the year needed fewer days to reach maturity due to a quicker accumulation of heat units (Dufault et al., 2006).

In conclusion, this study indicates that high tunnel systems can help increase the production potential of spring organic lettuce and will not exacerbate bolting, tip burn, or lettuce drop in butterhead or romaine lettuce in Georgia. The results illustrate that disease pressure and disorders related to heat or $\mathrm{RH}$ will vary with yearly weather conditions. Although different high tunnel structures were not evaluated, optimized natural ventilation was shown to maintain relatively similar environmental conditions (i.e., air temperature and $\mathrm{RH}$ ) on warm, sunny or humid days. 


\section{Literature Cited}

Agricultural Marketing Resource Center (AgMRC). 2015. Lettuce. 26 Aug. 2016. <http://www. agmrc.org/commodities-products/vegetables/ lettuce/ $>$.

Alves, E., C.L. Falk, J. Enfield, S.J. Guldan, and M.E. Uchanski. 2014. The economics of lowcost high tunnels for winter vegetable production in the Southwestern United States. HortTechnology 24:7-15.

Borrelli, K., R.T. Koenig, B.M. Jaeckel, and C.A. Miles. 2013. Yield of leafy greens in high tunnel winter production in the northwest United States. HortScience 48:183-188.

Carey, E.E., L. Jett, W.J. Lamont, T.T. Nennich, M.D. Orzolek, and K.A. Williams. 2009. Horticultural crop production in high tunnels in the United States: A snapshot. HortTechnology 19:37-43.

Chitrampalam, P., T.A. Turini, M.E. Matheron, and B.M. Pryor. 2010. Effect of sclerotium density and irrigation on disease incidence and on efficacy of Coniothyrium minitans in suppressing lettuce drop caused by Sclerotinia sclerotiorum. Plant Dis. 94:1118-1124.

Clarkson, J.P., L. Fawcett, S.G. Anthony, and C. Young. 2014. A model for Sclerotinia sclerotiorum infection and disease development in lettuce, based on the effects of temperature, relative humidity and ascospore density. PLoS One 9:e94049.

Dufault, R.J., B. Ward, and R.L. Hassell. 2006. Planting date and romaine lettuce cultivar affect quality and productivity. HortScience 41:640-645.

Economic Research Service (ERS). 2013. Table 10 Certified organic vegetables. Acres of tomatoes, lettuce, carrots, mixed vegetables, and unclassified vegetables by State, 1997 and 2000-11. 26 Aug. 2016. <http://www.ers.usda. gov/data-products/organic-production.aspx $>$.

Environmental Protection Adminstration (EPA) 2016. What climate change means for Georgia. 430-F-16-012. 15 June 2017. <https://www. epa.gov/sites/production/files/2016-09/documents/ climate-change-ga.pdf $>$.

Huber, L. and T.J. Gillespie. 1992. Modeling leaf wetness in relation to plant disease epidemiology. Annu. Rev. Phytopathol. 30:553-577.

Korczynski, P.C., J. Logan, and J.E. Faust. 2002. Mapping monthly distribution of daily light integrals across the contiguous United States. HortTechnology 12:12-16.

Kunkel, K.E., L.E. Stevens, S.E. Stevens, L. Sun, E. Janssen, D. Wuebbles, C.E. Konrad, II, C.M Fuhrman, B.D. Keim, M.C. Kruk, A. Billet, H Needham, M. Schafer, and J.G. Dobson. 2013. Regional climate trends and scenarios for the U.S. national climate assessment-U.S. global change research program. 29 Aug. 2016. $<$ https://scenarios.globalchange.gov/sites/default files/NCA-SE_Regional_Scenario_Summary_ 20130517 banner.pdf>

O'Connell, S., C. Rivard, M.M. Peet, C. Harlow, and F. Louws. 2012. High tunnel and field production of organic heirloom tomatoes: Yield, fruit quality, disease, and microclimate. HortScience 47:1283-1290.

Prohens-Tomás, J. and F. Nuez. 2008. Vegetables 1: Asteraceae, Brassicaceae, Chenopodicaceae, and Cucurbitaceae. Springer-Verlag, New York, NY.

Rogers, M.A. and A.L. Wszelaki. 2012. Influence of high tunnel production and planting date on yield, growth, and early blight development on organically grown heirloom and hybrid tomato. HortTechnology 22:452-462.

Runkle, E. 2011. Lighting greenhouse vegetables. Michigan State Univ. Expt. Floriculture Team. 22 Aug. 2016. <http://www.flor.hrt.msu.edu/ assets/Uploads/Lightingvegetables.pdf>.

Sanders, D. 2001. Lettuce: Horticulture information leaflet. NC Coop. Expt. Resources. 14 Nov. 2014. <http://content.ces.ncsu.edu/lettuce>.

Sydorovych, O., C.L. Rivard, S. O'Connell, C.D. Harlow, M.M. Peet, and F.J. Louws. 2013 Growing organic heirloom tomatoes in the field and high tunnels in North Carolina: Comparative economic analysis. HortTechnology 23:227-236.

Toland, B. and G. Lucier. 2011. U.S. Lettuce statistics 2011. Table 45. World lettuce production, 1961-2009. ERS. 26 Aug. 2016. $<$ http://usda.mannlib.cornell.edu/MannUsda/ viewDocumentInfo.do?documentID=1576>.

University of Georgia (UGA) Weather Network. 2016. College of Agr. Environ. Sci., Univ. of Georgia. 16 Aug. 2016. <http://www.weather. uga.edu/>.

USDA. 1968. Soil survey. U.S. Dept. Agr. Soil Conservation Serv. 16 Aug. 2016. <https://www. nrcs.usda.gov/Internet/FSE_MANUSCRIPTS/ georgia/clarke_oconeeGA1968/CO.pdf>.

USDA. 2012. Plant hardiness zone map. PRISM Climate Group-Oregon State Univ. 16 Aug. 2016. <http://planthardiness.ars.usda.gov/ $\mathrm{PHZMWeb} />$.

USDA. 2015. 2012 census of agriculture highlights: Organic farming. ACH 12-29. 15 Aug. 2017. $<$ https://www.agcensus.usda.gov/Publications/ 2012/Online_Resources/Highlights/Organics/ 2014_Organic_Survey_Highlights.pdf>.

Wallace, R.W., A.L. Wszelaki, C.A. Miles, J.S Cowan, J. Martin, J. Roozen, B. Gundersen, and D.A. Inglis. 2012. Lettuce yield and quality when grown in high tunnel and open-field production systems under three diverse climates. HortTechnology 22:659-668.

Waycott, W. 1995. Photoperiodic response of genetically diverse lettuce accessions. J. Amer. Soc. Hort. Sci. 120:460-467.

Zeng, W., W. Kirk, and J. Hao. 2012. Field management of Sclerotinia stem rot of soybean using biological control agents. Biol. Control 60:141-147.

Zhao, X. and E.E. Carey. 2009. Summer production of lettuce, and microclimate in high tunnel and open field plots in Kansas. HortTechnology 19:113-119. 